\title{
NAUKA PRAWA A WSPÓŁCZESNA ADMINISTRACJA PUBLICZNA
}

\section{PROBLEMY PRZYSZŁOŚCIOWE ADMINISTRACJI PUBLICZNEJ}

Po czasie przełomów kodyfikacji, nowych standardów, regulacji konstytucyjnych oraz prawa europejskiego współczesna nauka prawa poszukuje pragmatycznych paradygmatów. Pozytywizm chroni się przed swoim „niedomaganiem teoriopoznawczym” nurtem instrumentalizmu, zapożyczonym z ogólnych założeń filozofii nauki, czysty zaś normatywizm prawdopodobnie zanikł, ponieważ na etapie prawnie istotnym zjawisko subsumpcji przekroczyło poważnie ramy i granice logiki formalnej, wspartej na elastycznych nawet metodach interpretacji. Instrumentalizm, który wyrósł w czasach współczesnych jako nowa koncepcja, znajdując zainteresowanie szkół i poznania pozytywistycznego, ma wymiar synergiczny ${ }^{1}$. Przejawia się jako pojęcie konglomeratowe, dość złożone w różnych kulturach prawnych, a niemal aforystycznie staje się szansą na argumentowanie wielu działań prawnie ważnych. Wyraźne jest tu działanie sprowadzania do wspólnego mianownika. Proces cywilizacyjny wydaje się jednoznacznie pojmowalny tylko cząstkowo, podobnie jak jego opis w warunkach spiętrzonego nadmiaru. Powracaja jednak znaczące doktrynalne koncepcje i systemy poglądów filozoficznych. W istocie, aby pojąć procesy konwergencji globalnej w dostateczny i dostatecznie ogólny sposób, należy skupić się na prawie państwowym wewnętrznym najwyższego rzędu, a tym samym prawie administracyjnym, bez którego prawo państwowe nie funkcjonuje. Oczywiście sprzężenia występują także w ramach systemu prawa międzynarodowego i w prawie ponadnarodowym. Dodatkowo trzy te wymiary sa jednostronnie lub wzajemnie zależne. W prawie państwowym najogólniej trendy doktrynalne wyraża obowiazujące prawo konstytucyjne. Zarazem analiza przejawów i tendencji konwergencji uzmysławia potrzebę skupienia się na korelacji podmiotowości prawnej i władztwa prawnego. Właśnie w nauce na tym polu w szczególności z hipotez drogą deskrypcji powstają modele deskryptywne. Wyposażone w metody empiryczne stają się modelami badawczymi. W ich ramach funkcjonują hipotezy, koncepcje, twierdzenia, teorie, korelujące

\footnotetext{
${ }^{1}$ Warto tu przywołać N. MacCormick, Legal Reasoning and Legal Theory, Oxford 1978, s. 275 in. W tej materii nade wszystko zob. H. L. A. Hart, Pojęcie prawa, Warszawa 1998, s. 4, 12 i n., 121 i 127 .
} 
z określonymi metodami. W przyszłości zaś oczekiwać można jakichś postaci doktrynalnych.

Prawo konstytucyjne, administracyjne i administracja publiczna, jako istotna dziedzina struktury publicznej i normatywnej, poddane sa widocznej globalizacji ${ }^{2}$. Globalizacja jest dziś wszechobecnym procesem umiędzynarodowiania kultury, modelów konsumpcji dóbr i usług, rynków, finansów, zabijania, technologii, innowacji, interakcji podmiotowych i przedmiotowych, mody, polityki, a w konsekwencji także instytucji prawnych. Występuje w sferze społecznej, gospodarczej oraz prawnej i swoim nieodłacznym wpływem zdaje się współcześnie obejmować każde zagadnienie istotne w sferze publicznej, mając oczywisty wpływ i znaczenie w sferze prywatnej. Prowadzi do ujednolicania postaw i zachowań, powodując oczywiste i wyraziste zbliżanie się warunków, celów, możliwości i efektów podejmowania działań przez różne podmioty. Obraz tego zjawiska podlega wyobrażalnie trudnym syntezom i ujęciom generalnym w oczywistym strumieniu i różnorodności szczegółów. A dominacja szczegółu zaciera obraz ogólny i vice versa.

Można się spodziewać poważnych w najbliższej przyszłości problemów związanych z tą sytuacją administracji publicznej, w której występuje ona jako gwarant rzetelności unormowań konstytucyjnych i podmiot odpowiedzialny za poprawną realizację tego prawa, wyrastającego $\mathrm{z}$ dotychczas respektowanych wartości i przydającego obywatelowi całe wiązki uprawnień, a nawet praw podmiotowych.

Problemy gwarancyjne są poważniejsze od tych, które wyrażane są w ogólnej opinii. Dotyczą nawet zasad demokratycznego państwa prawnego, a także postrzegania i przestrzegania relacji trójpodziału władzy w braku skutecznej policji administracyjnej. Narastają zjawiska niekonstytucyjne ${ }^{3}$. Istnieje wiele form zagrożeń, które owe korelacje władztwa i podmiotowości prawnej rozstrzygają w sposób niepewny dla jednostki. W tej dziedzinie poruszane jest nawet zagadnienie aktualnej, zdaniem nowych studiów, „patologii demokratycznej” i problemów zasad demokracji, cechą wielu relacji współczesnego państwa może być bowiem dostrzegalna dekadencja, która przekłada się na życie polityczne i prawne w kulturze świata, przez zachowania jednostkowe ${ }^{4}$.

Pomiędzy pozytywną a funkcjonalną i pragmatyczną analizą prawa w kulturze prawnej jest jeszcze wiele czynników multiplikujących. Występuje bowiem możliwość integracji nauki prawa, charakterystycznej w dziedzinach doktrynalnych, a także integracji zewnętrznej, tj. możliwego zespolenia z in-

${ }^{2}$ W pewnym zakresie por. A. G. McGrew, P. Lewis, Globalisation and Nation-States, Cambridge 1992, s. 18. W tej dziedzinie zob. A. Błaś, Administracja publiczna w obliczu globalizacji, „Przegląd Prawa i Administracji” t. 50, Wrocław 2002, s. 65 i n.; I. Lipowicz, Administracja wobec wyzwań globalizacji, w: Z. Cieślak, I. Lipowicz, Z. Niewiadomski, Prawo administracyjne - część ogólna, Warszawa 2000, s. 37 i n. W zakresie zagadnienia zob. także A. Graham, Administracja publiczna w USA, w: A. Pawłowska (red.), Administracja publiczna-zagadnienia wstepne, Lublin 1999, s. 213.

${ }^{3}$ Por. A. Błaś, Niekonstytucyjne koncepcje samorzadu terytorialnego, w: S. Dolata (red.), Prawo samorzqdowe $i$ administracyjne, Opole 2000, s. 45 i n.

${ }^{4}$ Zob. także F. Fukuyama, Historia ładu politycznego. Od czasów przedludzkich do rewolucji francuskiej, Rebis, Poznań 2012, s. 18. 
nymi działami nauki. Współcześnie systemy prawne poddane są silnym procesom konwergencji i synergii ${ }^{5}$. Toteż perspektywa właściwego badania powinna przynajmniej w sposób refleksowy uchwycić pewien wymiar empiryczny, droga metod badawczych empiryzmu prawniczego, aby poszukiwać miar praktycznych oraz ustaleń zasadnych i sprawdzalnych. Samo poznanie prawa, oparte tylko na jego źródłach (fontes iuris cognoscendi) już w takim badaniu nie wystarczy.

\section{ADMINISTRACJA PUBLICZNA A PRYNCYPIA SYSTEMOWE}

Studia pragmatyczne zespalające duże ilości danych mają skomplikowany charakter. Muszą też uwzględniać niejednokrotnie obraz złożonych zależności ekonomicznych o charakterze globalnym ${ }^{6}$. Toteż charakterystyczna jest tu trudność ujęcia, podziałów czy typologii. W każdym razie problemy prawne powracają w tematyce, która była w przeszłości niemal rzadką idiomatyka pozytywizmu prawniczego ${ }^{7}$. Systemy, układy, relacje, w tym relacje prawne oraz struktury zależą od wielowymiarowych, zmultiplikowanych czynników, których zjawiskowość uzależniona jest od procesów międzynarodowych, dokonujących się w odległych centrach władzy, i od metod rządzenia, komunikacji, sygnału, w tym komunikacji prawnej lub społecznej. Prawo powszechne wewnętrzne, państwowe staje się hybrydową konstrukcją faktyczna, której elementy stanowią poglądy, zwyczaje, regulacje brane z ośrodków odległych politycznie, prywatnych i przemożnych gospodarczo i politycznie. W czasach globalnych relacji politycznych, transgranicznych korporacji i form unifikowania czy integrowania na etapie intensywnego prawa międzynarodowego i prawa administracyjnego w ramach systemu prawa międzynarodowego problem regulacji fundamentalnych i prawa konstytucyjnego jest odbiciem licznych tendencji koncepcyjnych i doktrynalnych o charakterze międzykulturowym. Synergia jest tu oczywista i realna konsekwencja. Niejednoznaczny proces wpływu i oddziaływania prawnego ma charakter kulturowy, niedostrzegalny czy niesformalizowany. Zjawiska procesów zglobalizowanego oddziaływania wydaje się, że mają pewne uzasadnione znaczenie poznawcze jako kompleksowy mianownik spostrzeżeń prawnych. Trzeba też zauważyć, że obok zjawisk tego typu i bezwzględnej czy tylko możliwej transpozycji generalnych norm prawnych rozwiną się mocniej zwłaszcza w Unii Europejskiej formy oddziaływania zindywidualizowanego za pomoca aktu administracyjnego. Podnosi się, że przestrzeń publiczna to podmiotowo-koncepcyjne ujawnienie natury

\footnotetext{
${ }^{5}$ W pewnym zakresie por. D. Buchanan, A. Huczynski, Organizational Behavior, Introductory Text, Prentice Hall 1997, s. 283; Ch. Elliot, System Safety and Law. Proceedings of First International Conference on System Safety, London 2006, s. 344-351.

${ }^{6}$ Zob. L. D'Arcy, C. Murray, B. Cleave, The Law and Practice of International Trade, Sweet \& Maxwell, London 2000, s. 669.

${ }^{7}$ Por. M. Grzegorczyk, Prawo kosmiczne, Zeszyty Naukowe UJ, Kraków 1973, s. 8 i n.
} 
i bytu homo politicus - ustalonego głównie i wciąż odkrywanego spostrzeżeniami nauk przyrodniczych, behawioryzmu i antropologii współczesnej ${ }^{8}$. Konwergencja ma dostrzegalne normatywistycznie i prawnopozytywne skutki praktyczne. Naturalnie była także przełamywaniem poglądu, w ramach którego pojęcie podmiotu w systemie prawa międzynarodowego stosowano tylko do państw9. Umowa społeczna w czasach konwergencji globalnej jest ponadpaństwowa i choć wydaje się terminem niewygodnym doktrynalnie, dostrzec można jej ramy. Nade wszystko umowa społeczna - jako dogodny model wyjaśnienia - ma dziś charakter konglomeratowy ${ }^{10}$.

Odrębną płaszczyzną konwergencji jest przestrzeń ponadnarodowa wyznaczana prawem Unii Europejskiej. Także problematyka podmiotowości powróciła tu wyraziście, zwłaszcza w kontekście prawa ponadnarodowego. Warto tu lapidarnie wspomnieć, że pojęcie „unii” funkcjonujace w licznych zakresach znaczeniowych sprowadza się najczęściej we współczesnym prawoznawstwie do pojęcia Unii Europejskiej, które jest korelantem pojęć współpracy, integracji, kooperacji, wspólnoty. Jednoznacznie rosnąca liczba zagadnień dotyczących prawa europejskiego nie wiąże się z wyjaśnianiem zagadnień podstawowych, a doktryna nadal ściera się argumentacyjnie nawet w kwestii samej podmiotowości prawnej Unii ${ }^{11}$. Konwergencja dokonuje się tu w sferze podmiotowej prawa i za jej pośrednictwem, obrazując podmiotowy lub często personalistyczny wpływ na system prawny, w tym prawo konstytucyjne i administracyjne. W prawie konstytucyjnym i administracyjnym wstępną konstatacja konwergencji prowadzacej do synergii jest wykrycie elementu znaczeniowego, podmiotowego lub władczego, o charakterze międzynarodowym. Nawet normy rozumiane pozytywistycznie należące do systemu prawa powszechnego wewnętrznego mają tu inny sens i walor, a zarazem inną faktyczna, empiryczna skalę oddziaływania.

Można też spojrzeć na Unię Europejska, korzystając z innych ujęć. Konstatacja tego, czy więcej ze swojej podmiotowości oddali obywatele państw na rzecz Unii, czy więcej władczości oddały na rzecz Unii państwa członkowskie, sprowadza możliwość traktowania Unii jako państwa państw, w którym budujące nową jakość ograniczenia suwerenności odnoszą się do państw, a nie do ich narodów. Nadto państwa pozostały podmiotami odpowiedzialnymi (w różnych sferach) przed własnymi obywatelami, a głównym kreatorem systemów prawnych obywateli w przeważającej części ingerencji publicznoprawnej po-

\footnotetext{
${ }^{8}$ Por. F. Fukuyama, op. cit., s. 48.

${ }^{9}$ Zagadnienia socjologii prawa w kontekście podmiotowym maja głęboki sens poznawczy. Ze współczesnej literatury warto przywołać: A. Pieniążek, M. Stefaniuk, Socjologia prawa. Zarys wyktadu, Zakamycze, Kraków 2000, s. 114; G. Rocher, Sociology of Law, w: International Encyclopedia of the Social \& Behavioral Sciences, 2004, s. 8544 i n; Ch. Perelman, On Legal Systems, „Journal of Social and Biological Systems” 7, 1984, nr 4 (October), s. 301 i n; F. Chazel, Social Structure, w: International Encyclopedia of the Social \& Behavioral Sciences, 2004, s. 15233 i n.

${ }^{10}$ Pojęcie i model umowy społecznej pochodzą z dzieł J. Locke'a, T. Hobbesa oraz J.-J. Rousseau. W tym zakresie por. F. Fukuyama, op. cit., s. 103, 104 i n.

${ }^{11}$ Por. G. Cornu, Vocabulaire juridique, Quadrige/PUF, 2007, s. 943-944. Zob. także F. Souty, Le droit et la politique de la concurrence de l'Union européenne, Montchrestien 2003, s. 11; O. Blin, Institutions européennes, Elipses, Paris 2008, s. 6 i n.; J. P. Jacqué, Droit institutionnel de L'Union européenne, Éditions Dalloz, 2006, s. 43.
} 
zostaje, jak dotychczas, wewnętrzna administracja publiczna, mimo ciagle rozbudowującej się strukturalnie (bezpośredniej lub powierzonej) i zadaniowo administracji unijnej. Administracja ta, przed którą staja coraz natarczywiej potrzeby i zadania z obszaru ochrony wspólnego interesu unijnego, funkcjonuje w coraz bardziej skomplikowanym materialnie lub proceduralnie mechanizmie różnego rodzaju dyspozycji. Kieruje jednak więcej decyzji do państw niż do zindywidualizowanych adresatów.

Proces konwergencji jest fenomenem natury faktycznej, empirycznej lub pragmatycznej. Państwo prezentuje tu pewien rodzaj eklektycznej doktryny, która opisuje nade wszystko konstytucja, opierając się na zasadach demokracji. A konstytucyjne aksjomaty prawne zależne są od stanu czynników doktrynalnych, a zatem także od czynników konwergencji.

Poszukiwania aksjomatów prawa wywodzi się najczęściej ze stanu zastanego w każdej kulturze prawnej ${ }^{12}$. Konstrukcje terminologiczne i poznawcze sa $w$ nauce prawa środkiem osiagania pewnego instrumentarium. $\mathrm{Z}$ natury rzeczy może być to jedna z cech kluczowych dość złożonego nurtu poglądów na temat instrumentalnego charakteru prawa - instrumentalizacji prawa ${ }^{13}$. Zagadnienie to jest z pewnością bardzo szerokie, a zaleta jest tu łaczenie zasadnych i wartych przyjęcia różnych trendów w zmiennych podstawach. Powstają konglomeratowe spostrzeżenia dotyczace przekrojowo wielu zagadnień ${ }^{14}$. W szczególności podkreślić można postulat, aby rozumienie dostarczanych przez teorię pojęć było czytelne i utrwalone ${ }^{15}$.

Przestrzeń publiczna podlega dziś silnemu oddziaływaniu procesów międzynarodowych. Dostrzegalne sa tu zjawiska paradoksalne, przekraczające nie tylko filozoficzno-praktyczną myśl o indywidualizmie, szansach i możliwościach. Tymczasem pozycja jednostki w prawie wewnętrznym i międzynarodowym wydaje się współcześnie podlegać wysokim standardom i gwarancjom. Widoczne jest jednak wyraźne niedomaganie warstwy normatywnych rozumowań, co ma wpływ nie tylko na niepoprawność działania samej administracji publicznej, lecz także na petryfikację negatywnych opinii publicznych.

12 Zob. J. Jendrośka, Narzędzia badania prawa administracyjnego, „Przegląd Prawa i Administracji”, t. 50, Wrocław 2002, s. 149 i n. W tej dziedzinie zob. T. Rabska, Podstawowe pojecia organizacji administracji, w: J. Starościak (red.), System prawa administracyjnego, t. 1, red. T. Rabska, J. Jendrośka, J. Łętowski, Ossolineum, Wrocław 1977, s. 256.

13 Por. A. Vermeule, Instrumentalisms, book review, „Harvard Law Review” 120, 2007, nr 8, s. 2114. Zob. też W. Gromski, Autonomia i instrumentalny charakter prawa, Kolonia Limited, Wrocław 2000, s. 83 i n.

${ }_{14}$ Wiedza o systemie prawa musi mieć z natury praktycznej pewien wyraz zamknięty, nie wszystkie informacje da się analizować, stosować, wykorzystywać czy przechowywać. Pojęcie systemu jest pojęciem narzędziem. W tej materii zob. F. Logchamps, O używaniu pojęć w naukach prawnych, „Zeszyty Naukowe UWr”, Prawo, 1960, nr 7, s. 11 i n. Por. także F. Studnicki, Wprowadzenie do informatyki prawniczej, Warszawa 1978, s. 14. W zakresie rozważań zob. K. Opałek, Problemy metodologiczne nauki prawa, Warszawa 1962, s. 163; A. Redelbach, S. Wronkowska, Z. Ziembiński, Zarys teorii państwa i prawa, Warszawa 1992, s. 219, 221; K. Ajdukiewicz, Logika pragmatyczna, Warszawa 1975, s. 48. W innym kontekście por. także A. Bator, Instrumentalizacja prawa a problem niezgodności $i$ luk $w$ systemie prawa (charakterystyka założeń badawczych), „Przegląd Prawa i Administracji”, t. 50, Wrocław 2002, s. 39 i n. W podobnym kontekście zob. J. Woleński, Logiczne problemy wykładni, Warszawa-Kraków 1972, s. 43 i 60.

${ }_{15} \mathrm{~W}$ tej dziedzinie zob. H. L. A. Hart, op. cit., s. 4, 12 i n., s.121 i 127. 
Współczesne procesy administrowania w sprawach publicznych, a w szerszym ujęciu - procesy normotwórcze, wykonawcze, faktyczne, dynamika i statyczność systemów, przenikaja się wzajemnie z pewnymi trendami ogólnymi. Systemy w wyniku kontaktów czy podporządkowania wpływaja na siebie zamiennie, oddziałujacc standardami, faktycznymi i pragmatycznymi czynnikami wymiany. Czerpią tu ze wspólnoty kulturowej, podobnych odniesień, wspólnych znaczeń.

Europejska kultura prawna wypracowała najważniejsze $\mathrm{z}$ form determinant, koncepcji, przestrzeni materialnych i proceduralnych. W swym dualizmie, w postaci kontynentalnej czy w wymiarze common law, wzbudziła pojmowanie modernizmu prawa $\mathrm{w}$ dziedzinach regulacji sytuacji jednostki, wszelkich korelacji zasadniczych między zjawiskami władztwa i bytami konstrukcyjnymi podmiotowości. A obrazu tego nie zamazuje nawet różnorodność poglądów. Najbliższą regulacyjną i uporządkowaną formą w tym zakresie jest przykład integracji europejskiej, w której trzonem i głównym łącznikiem regulacji jest prawo administracyjne ${ }^{16}$.

Dojrzał tu także rząd innych problemów teoretycznych. Procesy faktyczne, normatywne i kulturowe wydobywają w teorii nową dziedzinę badań nad administracją w organizacjach międzynarodowych (administration in international organizations). Właściwie szerzej mówić można o administracji w relacjach międzynarodowych - administracji internacjonalnej ${ }^{17}$. Prawo podąża tu za wskazaniami administracji, ale i administracja zdaje się także podążać za prawem, choć oczywiście ma je przede wszystkim wykonywać. Zakres wskazówek poprawności tych ruchów i ich funkcji jest wobec nowości zagadnień zjawiskiem nie tylko niezbędnym, ale nawet faktycznie niepoznanym dostatecznie. Z natury rzeczy potrzeba tu regulacji, zwyczaju, technik, a nawet pragmatyk czy strategii. Faktyczne ograniczenia, liczne obowiązki, krótkość terminów, czy zasięg przestrzeni powoduja, że podmioty w prawie międzynarodowym i podmioty prawa międzynarodowego stają się w całym obszarze prawnej refleksji ważnym praktycznym empirycznym czynnikiem i współczynnikiem oceny prawa (empirical factor). Podmiotowość międzynarodowoprawna jest zjawiskiem o dużym potencjale wniosków intelektualnych.

Rozumienie administracji nowoczesnej - neomodernistycznej nie jest jednak jednoznaczne z ujęciem administracji innowacji, a tym bardziej elektronicznej administracji publicznej, niemniej jednak łatwo poddaje się opisowi. Dostrzega się w nim cechy elastyczności i różnorodne koncepcje deontologiczne i prakseologiczne, zróżnicowanie form prawnych działania, dbałość

${ }^{16}$ Zob. w szczególności J. Supernat, Administracja Unii Europejskiej. Zagadnienia wybrane, Wrocław 2013, s. 47. W tej dziedzinie zob. także K. Kiczka, Krajowy organ administracji publicznej w prawie unijnym, Kolonia Limited, 2013, passim.

${ }^{17}$ W tym kontekście por. T. D. Grant, Admission to the United Nations, Leiden-Boston 2009, s. 1 i n. W innym aspekcie zob. D.-U. Galetta, Procedural Autonomy of EU Memeber States: Paradise Lost? A Study on the "Functionalized Procedural Competence" of EU Member States, Springer 2010, s. VII; I. Goldner Lang, From Association to Accession. How Free is the Free Movement of the Persons in the EU, Eleven International Publishing, 2011, s. 19 i n. O prawie europejskim zaś w dziedzinie obywatelstwa zob. F. Goudappel, The Effects of EU Citizenship, T. M. C. Asser Press, 2010, s. 8 i n. 
o aspekty psychologiczne i behawiorystyczną odpowiedniość, ekspozycje zasad życzliwości i działania pro homine, administrowanie jakościa, kooperację z innymi podmiotami w kształtowaniu innowacyjności usług, utrwalanie zaufania i koncepcje umowy społecznej, wprowadzanie negocjacji, znaczenie czynników skuteczności i efektywności. A kategorie standardów administracji publicznej, procedury, zasady państwa prawnego ${ }^{18}$, zasady podziału władzy, demokratyczny system rządu i rzetelność działania prawnego zyskują w społeczeństwie nowych technologii nowa jakość.

Powracajace zagadnienia mają odległy i stary motyw. Wspomniany tu Placidus, który prawdopodobnie zastosował pojęcie państwa prawnego, rozważania te odnosił do roli struktur podmiotowych w dążeniu i dywersyfikowaniu szczęścia. Było to zatem spojrzenie konkretnie i personalistycznie eudajmonistyczne. Prawdopodobnie nie używali tego pojęcia Immanuel Kant ani Wilhelm von Humboldt, chociaż historia doktryn kojarzy ich rozważania z doktryną liberalnego państwa prawnego. Poglądy te dotyczyły kwestii zapewnienia sobie przez jednostkę bezpieczeństwa niejako we własnym zakresie. Kształtowano w ten sposób liberalne rozumienie zasady państwa liberalnego. Konstatowano zasadę, że podstawową rolą państwa jest zapewnienie bezpieczeństwa. Państwo nie mogło się zatem w ramach tej koncepcji troszczyć o dobrobyt czy szczęście obywateli. Interwencja na gruncie ochrony własności i wolności mogłaby nastapić tylko dla ochrony ważnego interesu jednostkowego, zapewnienia porządku i bezpieczeństwa publicznego. Kant rozwijał jednak pewna koncepcję na temat demokratycznego państwa prawnego. Państwo było w tym założeniu związkiem ludzi o wspólnych celach, związkiem jednostek, pozostających pod rządami prawa. Zasada kierowania się rozumem prowadzi do realnych ograniczeń, a racjonalne prawo zawarte w ustawie doprowadza do wyrzekania się nieograniczonej wolności w celu zapewnienia dobra innego rzędu. Konstytucja w państwie powinna być republikańska, aby zapewnić wolność, równość, niezależność oraz zasady systemowe. Wywodzi się z pierwotnej umowy społecznej, na której opiera się całe ustawodawstwo ${ }^{19}$. Racjonalne prawo można rozciagnąć na prawo międzynarodowe w celu stworzenia związku narodowych państw, który zapewni pokój na świecie (Völkerbund).

W ogólności doktryna i koncepcja były formułowane przeciw despotyzmowi władzy jednostek przez zapewnienie ludzkiego dobra wspólnego. Dobro to, realizując najpełniej dobro jednostkowe, było postrzegane jako podstawowe

18 Ich treść zawiera dzieło J. W. Placidusa Literatur der Saatslehre - Ein Versuch, wydane w Strasburgu w 1798 r. A. H. Müller stwierdził niedługo potem, że organiczne państwo prawne musi być ograniczone w obszarze, musi być zamkniętą, rzeczywistą jednostką por. Z. A. Maciag, Kształtowanie zasady państwa demokratycznego prawnego $i$ socjalnego w Niemczech (do 1949), Białystok 1998, s. 69. W tej materii por. D. Dudek (red.), Zasady ustroju III Rzeczypospolitej Polskiej, Warszawa 2009, s. 157 i n. W kulturze anglosaskiej istnieje koncepcja rule of law. Zob. także A. V. Dicey, Introduction to the Study of the Law of the Constitution, Indianapolis 1982, s. 110 i n. W tej dziedzinie zob. A. Błaś, J. Boć, K. Complak w: J. Boć (red.), Konstytucje Rzeczypospolitej oraz komentarz do Konstytucji RP z 1997 roku, Wrocław 1998, s. 34 i n. Por. także L. Garlicki, Polskie prawo konstytucyjne. Zarys wyktadu, Warszawa 2002, s. 61.

19 Por. S. Pinker, The Better Angles of Our Nature. The Decline of Violence in History and Its Couses, Viking Penguin, 2011, s. 59 i 166. 
„prawo człowieka” utożsamiane z wolnością. Koncepcja zaś eksponowała wolę parlamentu, wolność, własność, znaczenie woli indywidualnej oraz państwo jako główny podmiot władztwa. W rzeczywistości polskiej demokracji wartości te od 1989 r. nieraz były przedmiotem szerokiej deliberacji i wyroków Trybunału Konstytucyjnego.

Intensywność eksponowania współczesnego polskiego państwa jako państwa prawnego nie oznacza istnienia pełnej regulacji prawnej wszystkich wartości, z których normatywnie i orzeczniczo buduje się to państwo. W położeniu takim znajduje się wiele tematów szczególnych, a wśród nich brak dostatecznej regulacji funkcjonowania systemu partyjnego i kwestii konstytucyjnego unormowania zasady podziału władz. Dokładny opis treści i zasięgu władczego działania podmiotów z konstytutywnego trójpodziału, jeśli ma ambicje odzwierciedlenia rzeczywistości, musi uwzględniać wszechogarniająca funkcję partyjności, która - aczkolwiek nieregulowana prawem - obejmuje powoli całość istotnych w państwie stosunków publicznych. Jeśli zatem uznać niezależną pozycję sądownictwa, choć oczywiście też w niepełnym zakresie z powodu powoływania sędziów przez inne władze, i zatrzymać się w kontekście partyjności, której oczywiście sędzia z Bordeaux o nazwisku baron de la Brède et de Montesquieu ani nie widział, ani nie mógł widzieć, tylko na władzy ustawodawczej i na administracji publicznej, to dochodzimy do takiego obrazu tych władz, na którym ich wzajemna niezależność i efektywność kontroli są mocno zamazane, a w wielu ważnych mechanizmach państwa w ogóle nie istnieją. Zwycięska partia, czy też koalicja partii, dyscyplinuje znaczną część stosunków między władzą ustawodawczą a władzą wykonawczą jedną idea, jednym korpusem ludzi i jednym posłuszeństwem. Trzeba jednakże przyznać, że jest to obraz nie tylko polski, ale jest to obraz prawie całej Europy i świata. Dochodzi do tego element zniekształcenia administracji samorządu terytorialnego przez zbyt silne oddziaływania partyjne w wyborach do organów jednostek samorządu terytorialnego i w ich funkcjonowaniu. Wszystko to razem nadaje inny ton współczesnej idei i praktyce demokracji w państwach prawnych.

Nie wiadomo, jak zróżnicowany zakres problemów przyniesie w najbliższej przyszłości dalsza realizacja dziś wpisanej do polskiej Konstytucji monteskiuszowskiej zasady. Spotykamy bowiem np. poglądy niejasno oddające idee umieszczania całej organizacji i funkcjonowania samorządu terytorialnego w obrębie władzy wykonawczej. Także Trybunał Konstytucyjny nietrafnie ustalił, wprawdzie w 1996 r. (a więc w czasie sprzed Konstytucji z 1997 r.), że do ustroju samorządu terytorialnego nie ma zastosowania zasada podziału władz. Toteż sytuacja wymaga koniecznego wskazania następujących kwestii: faktem jest, że podział władzy z art. 10 Konstytucji RP odnosi się do ustroju (całego) Rzeczypospolitej Polskiej; że w obrębie tego ustroju funkcjonują takie podmioty, jak Sejm, Senat, Prezydent i Rada Ministrów, sądy i trybunały, tak więc ustrój ma charakter organizacyjny i funkcjonalny, a nie jakiś „,charakter polityczny"; że ta sama Konstytucja reguluje i administrację rządową, i administrację samorządu terytorialnego, z tym że tę ostatnią szerzej i głębiej; że ta administracja samorządowa działa w państwie polskim i rozważając administrację rządową jako część administracji publicznej oraz jednocześnie 
funkcjonującą administrację samorządu terytorialnego, wyróżniamy te same podstawy i te same funkcje. Obydwie administracje funkcjonuja w ramach państwa, obydwie respektuja jedno prawo, obydwie maja legitymacje do tworzenia prawa, obydwie dysponują tą samą władczościa, obydwie są jednocześnie i zmiennie powołane do prowadzenia administracji (władzy) publicznej przez realizację zadań publicznych zawsze służących mniejszemu lub większemu ogółowi. W tych okolicznościach żadne rozumowania nie mogą doprowadzić do wniosku, że jedna administracja jest objęta zasadą podziału władzy, a druga - nie ${ }^{20}$.

Społeczna, funkcjonalna i normatywna waga aktów prawa miejscowego, w sytuacji ciagle nieostatecznego ustalenia ich zakresu, pociaga dziśs za soba dalsze eksponowanie władztwa samorządu terytorialnego. Aktualna droga tych przedsięwzięć wiedzie przez zamysł wzmacniania roli obywateli, przez poszerzanie i dalszą instytucjonalizację współudziału mieszkańców w funkcjonowaniu samorządnej władzy publicznej oraz przez rozbudowanie form współdziałania w ramach systemu władzy samorządoweje ${ }^{21}$. Zamysł ten doprowadza do postawienia poważnych pytań o granice publicznoprawnych zachowań wyznaczonych normatywnie. Dokładnie chodzi o to, by ustalić równowagę między dotychczasowymi prawnie określonymi publicznymi uprawnieniami podmiotów samorządu terytorialnego a między możliwością i zakresem przekazania mieszkańcowi dotychczas publicznoprawnych przedsięwzięć na drogę zindywidualizowanego postępowania administracyjnego o wszechogarniajacym zakresie interesu prawnego i uniwersalizacji zasięgu pojęcia strony. To jest nowy problem nauki prawa administracyjnego powstający na historycznym tle ciagłego niedosytu legalnych i kreacyjnych działań obywatela.

\section{ADMINISTRACJA WOBEC KRYZYSU}

Administracja publiczna podejmuje takie inwencje i wprowadza takie rozwiązania, których nikt poza nią nie jest w stanie kompetencyjnie podjaćc w obudowanym odpowiedzialnością działaniu czy zaniechaniu w sferze ważnej społecznie ${ }^{22}$. Przypomina się Anatol France, który pisał, że administracja rządzi źle, ale że jej to wybacza, ponieważ trochę rządzi.

20 J. Boć, w: A. Błaś, J. Boć, M. Stahl, K. M. Ziemski, Prawne formy działania administracji, w: System prawa administracjnego, t. 5, red. R. Hauser, Z. Niewiadomski A. Wróbel, C. H. Beck, Warszawa 2013, s. 98.

${ }^{21}$ Zob. bliżej M. Stahl, gdy analizuje prezydencki projekt zmian ustrojowych samorządu terytorialnego, O projekcie zmian ustrojowych samorzadu terytorialnego, „Administracja. Dydaktyka. Praktyka" 2011, nr 4, s. 132 i n.

${ }_{22}$ Nadzwyczajną aktualność ma fragment: „Ostatecznie cóż mi z tego, że władza jest wszechobecna, że czuwa zawsze nad tym, bym bezpiecznie zażywał przyjemności, że wyprzedza każdy mój krok, by usunąć mi z drogi niebezpieczeństwa, zanim zdążę o nich pomyśleć, jeżeli ta sama władza, która tak usilnie oszczędza mi przykrości, jest zarazem absolutną panią mojej moralności i mojego życia, monopolizuje wszelki ruch i wszelkie istnienie do tego stopnia, że wszystko usycha, kiedy ona marnieje i wszystko usypia, kiedy ona zapada w sen - wszystko umiera razem z nią”. Istotny ten cytat pochodzi z dzieła A. de Tocqueville’a, O demokracji w Ameryce, tłum. M. Król, wstęp J. Baszkiewicz, PIW, Warszawa 1976, s. 89. 
Także współcześnie postęp i uaktywnianie są domeną działań administracyjnych. A jeszcze stosunkowo niedawno element organizatorski, eksponujący łącznie najistotniejsze rysy działania publicznego, wbudowany był w polskiej literaturze nawet $\mathrm{w}$ definicję administracji, nierzadko jako jej najważniejszy element, czy nawet jedyny składnik. Oczywiście funkcja organizatorska jako społecznie intelektualna cecha jest dziś odsunięta od dotychczasowego znaczenia, ale funkcja zaspokajania ludzkich potrzeb wynikających ze współżycia w społecznościach, państwach i związkach państw nie może ulec jakiemukolwiek nadwerężeniu. Zwłaszcza tam, gdzie ekspozycja potrzeb człowieka długo przebijała się na swoje czołowe miejsce wśród celów i zadań administracji. Tymczasem kiedy wszyscy wciąż oczekują wszystkiego właśnie od administracji publicznej, widzianej jako emanacja państwa, świadomość fenomenu tego procesu wydaje się wciąż niedostatecznie uwypuklana. Nawet wtedy gdy na niepolskim obrazie lud walczy i śpiewa na barykadach, ale płacić każe administracji.

Etap współczesnego kryzysu światowych rynków i gospodarek datowanego na rok 2009 spowodowały sytuacje, które zwłaszcza w dziedzinie finansów publicznych osiagnęły niebywałe wyzwanie dla administracji. Jakość i skala tego wyzwania polegały na decyzjach, których ramy miały brać pod uwage ogromne i zmasowane ilości czynników o charakterze transnarodowym i międzysystemowym. Truizmem może tu być myśl, że gospodarka jest w skali globalnej systemem naczyń połączonych, układem relacji i wiązek zależności. Najgłębsze analizy nie mogły ustalić tu skutecznych modeli. Uznane podstawy ekonomii współczesnej stawały się mniej pewne. Zjawisko behawiorystyczne i psychologia rynku stały się zasadniczym czynnikiem $\mathrm{kreacji}^{23}$. I ciagle wydają się istotną motywacją współczesnych procesów w przestrzeni publicznej wewnętrznej i międzynarodowej ${ }^{24}$. Nadto dochodza do tego ostatnio poważne problemy polityczne o międzynarodowym charakterze, i tu także właśnie od administracji publicznej oczekuje się ich łagodzenia czy rozwiazywania.

Kryzys gospodarczy w świecie jest zdany na przeciwdziałania cząstkowe, ale kryzys w Unii Europejskiej jest przedmiotem całościowych przedsięwzięć decydujących w niej organów. Wzmacnia więc administracja unijna siłę oddziaływań centralistycznych we wszystkich podstawowych obszarach jej działania, tj. zarówno w sferze stanowienia planów, programów, aktów ustawo-

${ }^{23}$ Por. J. Gerber, International Economics, Pearson, 2011, s. 2 i n.

${ }^{24}$ Por. Ch. De Cooker (red.), Accountability, Investigation and Due Process in International Organizations, Martinus Nijhoff Publishers, Leiden-Boston 2005, s. IX i n.; A. Aust, Modern Treaty Law and Practice, Cambridge University Press, s. 16 i n.; J.-M. Eymeri-Douzans, J. Pierre, Administrative Reforms and Democratic Governance, Routledge Taylor \& Francis Group, 2011, s. 1; A. Aust, Handbook of International Law, Cambridge University Press, 2010, s. 2 i n.; K. J. Alter, The European Court's Political Power. Selected Essay, Oxford University Press, 2009, s. 3 i n.; N. W. Barber, The Constitutional State, Oxford University Press, 2010, s. 2 i n.; M. Broberg, N. Fenger, Preliminary References to the European Court of Justice, Oxford University Press, 2010, s. 1 i n.; Ö. B. Bodvarsson, H. van den Berg, The Economics of Immigration. Theory and Policy, Springer-Verlag 2009, s. 2 i n. 
dawczych czy aktów delegowanych, jak i w sferze działalności wykonawczej, a w tym działalności kontrolnej. A zarys tego scentralizowania narusza dotychczasowe zasięgi zdecentralizowania czy enklawy wolności i własności gospodarczej podmiotów krajowych.

Kryzysy mają różne postacie. Objawiają się wraz z długotrwałą lub pozyskaną gwałtownie wiedzą obywateli, drugi raz zaś z odsuniętą w czasie społeczną wiedzą o skumulowanych trudnościach funkcjonowania większej całości. Reagując na kryzys, administracja publiczna realizuje prawo już obowiązujące albo tworzy lub inicjuje nowe prawo.

Główny problem oceny reakcji wykonawczych administracji sprawdza się do czasu podjęcia przeciwdziałań, ich odpowiedniości i wystarczalności dostępnych środków. Natomiast w sytuacji braku prawa bezwzględna odpowiedzialność administracji obejmuje własna prawotwórczość. Odpowiedzialność ta słabnie w pozostałej sytuacji, gdy nawet dobrze wymyślone rozwiązania dostają się w tryby politycznej oceny w parlamencie.

Można się też w razie potrzeby natychmiastowej reakcji na bulwersujace fakty społeczne, połączone z nienależytym udziałem czy z zaniechaniem administracji publicznej, zwrócić ku pomysłom kreacji podmiotów o funkcjach i kompetencjach generalnej policji administracyjnej, ale zamysł taki nie może kolidować z konstytucyjnymi ramami podziału władzy.

Kryzys w kraju doprowadza do powstania zjawiska inflacji prawa wynikłego ze złożoności opinii na temat dróg dążenia do polepszenia sytuacji droga prawna. Na przykład w wyniku deregulacji podmioty większej rangi zostały wzmocnione, deregulacja zaś osłabiła jeszcze bardziej podmioty słabsze, funkcjonalnie ograniczajac im interes jednostkowy. Dyskurs polityczny wyprzedził tu prawo w sposób znamienny dla demagogii czasów potrzeb szczególnych. Poszukiwanie środków wpływa na znaczenie budżetowego podejścia w procesie subsumcji norm i może prowadzić do „kombinowanych” wykładni. Pojawiające się projekty partycypacji częściowo odwracają uwagę społeczeństwa od wykluczania z podejmowania głównych decyzji. A dla podmiotów stosowania prawa wartość konstrukcji praw podmiotowych może być nawet w podstawach dyskutowana czy podważana. Korelacje interesów stają się ewidentnym obliczem prymatu interesów wspólnoty i nakazują analizowanie znaczenia mechanizmu gwarancyjnego w funkcjonowaniu administracji. Administracja staje nie tylko przed potrzebą społeczna, ale i niezaspokojoną potrzebą własna, a nawet brakiem intelektualnego instrumentarium zdefiniowania swojej sytuacji w celu podjęcia działań, w tym działań prawnie ważnych ${ }^{25}$. Ponownie warto tu podkreślić docenienie w racjonalnych okolicznościach mechanizmu

25 Por. F. Longchamps, Założenia nauki administracji, Wyd. UWr, Wrocław 1994, s. 216. Uniwersalna wydaje się tu szczególnie uwaga: „O cóż w sumie chodzi? Jest pewien typ zjawisk społecznych [...] i nader złożony, które są w części wynikiem stosunków politycznych i gospodarczych, a w części czynnikiem przemian w tych stosunkach”. Wartość tej refleksji przejawia się także w innej ważnej konstatacji: „Ustalając składniki układu administracyjnego, trzeba jako punkt wyjścia wziąć pod uwagę, że rzeczywistość układu leży w czym innym niż rzeczywistość zjawiska administracyjnego" (ibidem), s. 111. 
centralizacji i ujęć generalnych w funkcjonowaniu, zwłaszcza zaś w warstwie teleologicznej czy też w celowości planowania. Zjawisko kryzysu nie sprzyja postawom etycznym i dbałości o służebną funkcję administracji, która mając nieodzowne znaczenie, nie ma ani nie może mieć analogii.

\section{Z REFLEKSJI OGÓLNYCH}

Problem procesów decyzyjnych $\mathrm{w}$ administracji pozostaje $\mathrm{w}$ fascynującym związku z pytaniem, czy polityka wobec prawa administracyjnego i zasięg ingerencji są sprzężone z ustabilizowanym układem wartości ${ }^{26}$. Stałość modeli wydaje się proporcjonalna do efemeryczności funkcjonalnych doktryn społecznych. Tymczasem wartość działania inteligentnego jest jednak dość uniwersalna, a na pewno pożądana ${ }^{27}$. Nie chodzi w takim działaniu wyłącznie o mechanizmy prawne. Na przykład procesy decyzyjne administracji innowacji, choć są starą teorią i trwała praktyka, a nie sa tak nowe, by odrywać je od podmiotowości, a nawet jednostkowego personalizmu, mają szczególne znaczenie.

Administracja w sensie podmiotowym stanowi taka organizację, która wpisuje się w ramy urzeczywistnień idei humanistycznych, a przynajmniej takie spodziewane oczekiwania się wobec niej wysuwa ${ }^{28}$. Faktyczne efekty prawa sa doskonałym probierzem oraz indukcyjnym modelem badania prawa ${ }^{29}$. W państwie prawnym, które jest najżywotniejsza, najbardziej humanistyczną i wartościową konstrukcją publiczną współczesnych czasów, każdy akt, wszystkie plany i koncepcje poprawy administracji wracaja do sfery wartości. Powracają stare modele pojmowania prawa i przestrzeni publicznej z perspektywy kompleksowych modeli etyki i wartości. Stałość ta zasługuje na odnotowanie i łączy zadziwiająco idealizm czasów dawnych i współczesny pragmatyzm ${ }^{30}$.

Jednocześnie daje się zauważyć ambiwalentność zasadniczych kierunków procesów współczesnych, a w tym doktryn, aksjomatów, metod i zasad organizacji i funkcjonowania administracji publicznej, w której wyraźnie dostrzegalny jest, w wielu miejscach, syndrom fasady decentralizacji. Wywodzi on swoja popularność ze zrozumiałych przesłanek nieekskluzywnych i liberalnych nurtów uczestnictwa, sens społeczny zasady władztwa demokratycznego bowiem opiera się właśnie na partycypacji. Także koncepcja teorii demokracji jest op-

${ }^{26}$ Por. A. Puszko, Wptyw przemian cywilizacyjnych na paradygmat administrowania przez prawo, w: J. Zimmerman, P. J. Suwaj (red.), Wptyw przemian cywilizacyjnych na prawo administracyjne i administracje publiczna, Wolters Kluwer, Warszawa 2013, s. 127 i n.; J. Wegner-Kowalska, Administracja w czasach kryzysu, w: J. Zimmerman, P. J. Suwaj (red.), op. cit., s. 29.

${ }^{27}$ Zob. J. Boć, Administracja publiczna jako organizacja inteligentna, w: A. Błaś, J. Boć, J. Jeżewski, Nauka administracji, Kolonia Limited, Wrocław 2013, s. 369 i n.

${ }^{28}$ Por. J. Habermas, Strukturalne przeobrażenie sfery publicznej, PWN, Warszawa 2007, s. 55 i n.

${ }^{29}$ Por. P. Cane, An Introduction to Administration, Oxford 1996, s. 132 i n.

${ }^{30}$ Por. A. MacIntyre, Dziedzictwo cnoty. Studium z teorii moralności, PWN, Warszawa 1996, s. 60 i n. 
arta na liberalnym współuczestnictwie. Toteż zbliżenie jednostki do władzy jest koniecznym scalaniem współczesnej idei społeczeństwa obywatelskiego z ideami postępu. Hasła pluralizmu przy całej ich zasadności przejawiają się także w dzisiejszym populizmie, którego złożone metody mają coraz głębsza artykulację i cechują się zawiłością argumentów. Decentralizacja to nie tylko zbliżanie kompetentnych organów do obywatela i ruch atrybutu władzy, ale zarazem to przesuwanie wszelkich współobecnych elementów i potrzebnych jej środków. Niemniej warto zauważyć, że jeżeli wyrównywanie gospodarcze w wewnętrznym systemie jednostek samorząów terytorialnych jest - zdaniem Trybunału Konstytucyjnego - niezgodne z Konstytucja, to założona w tej samej Konstytucji struktura i założone funkcjonowanie samorządów terytorialnych zostały ustalone co najmniej niesprawiedliwie. Zreszta warto dodać, że w polskim systemie bogactwo niektórych gmin nie wynika z mądrości wybranych radnych, lecz z lokalizacji potencjału gospodarczego i z systemu podatkowego.

Tymczasem czasy współczesne modelują retrospektywnie uzasadnione znaczenie podmiotu większego w strukturze. Wiedza ta mogłaby wstrzasać opinią publiczna, ale być może jest już jej znana. Jednocześnie pluralizm funkcjonuje nie tylko wertykalnie, ale także jest zjawiskiem horyzontalnym. W administracji nowe potrzeby wymagają wyższej i rosnącej w znaczących skalach ilości i grup środków. Utrzymanie sfery czy działu może być zdecydowanie trudniejsze lub bardziej kosztowne niż jego wykreowanie. A i nowe struktury w organizacji administracji publicznej będą wyraźniej potrzebne, zwłaszcza te, których celem będzie zapewnienie akceptowanych norm wolności w przebiegach informacyjnych i komunikacyjnych oraz ochrona istotnych interesów człowieka, której brak jest widoczny coraz mocniej. Nadto zasięg podporządkowania organom Unii, regionalizm, nowe technologie, struktury podmiotowe relacje kompetencji w państwie unitarnym zyskują aktualne znaczenie w wymianie argumentów o procesach decentralizacji i centralizacji.

Warto tu zauważyć, że żyjemy w przestrzeni administracji publicznej, w rzeczywistości wielu pozorów szerokiej decentralizacji, której ekspozycja zyskuje nawet ramy pewnej metateorii. Faktem, ale i tendencja, choć często zawoalowana, jest centralizacja, zauważalna zarówno w administracji publicznej, także w administracji samorządu terytorialnego, jak i jeszcze intensywniej w podmiotach prywatnych, także tych, które swoje funkcjonowanie opierają na stosunkach umownych. Wstępnym etapem otwierania innowacyjnej sfery społecznej jest pragmatyczne regulowanie oraz konstruowanie infrastruktury wykonawczej. A wartości skutecznej syntezy problemów trudno odmówić racji. Nade wszystko władztwo administracyjno-prawne jest w wielu miejscach scentralizowane. Większe szanse, znaczniejsza innowacyjność, zwiększają tu postać społecznego ryzyka. Nadto istotny tu czynnik ponadnarodowy jest wprawdzie oddalony, ale i bezpośrednio istotny. Trwa Unia Europejska w bezpośredniej skuteczności prawnej, zasadniczej roli dla europejskiej kultury prawnej ${ }^{31}$.

${ }^{31}$ Por. I. Goldner Lang, op. cit., s. 19 i n. W dziedzinie tej zob. F. Goudappel, The Effects of EU Citizenship, T. M. C. Asser Press, 2010, s. 8 i n. Warto przytoczyć w szczególności także: J. Barcik, 
W jakim więc stopniu współcześnie dostrzegalny model systemu funkcjonowania - również w kontekście układu partyjnego - jest zdecentralizowany? Wokół problemów pojmowania zasad współczesnego demokratycznego państwa i państwa prawa - w wielu obszarach - unosi się tu nierzadko mitologiczna funkcja spostrzeżeń oddalonych od praktyki. Zatem wyzwaniem doktryny prawa publicznego, a nade wszystko nauki prawa administracyjnego, jest w szerokiej i intensywnej skali ciagłe poszukiwanie dostatecznie wyraźnych paradygmatów sprawiedliwie społecznych rozstrzygnięć i wszelka oparta na prawie ochrona jednostki, obywatela, człowieka ${ }^{32}$. Obawa i wyzwanie sięgaja tu tak daleko, że pojęcie tego, co sprawiedliwe, wydaje się oddaloną emanacja dziejową pojmowania tego, co bezprawne lub nieużyteczne. Zmienności i różnice teoretyczne pojęć tego bytu, zależności czy potencjalności działań maja współcześnie wymiar potrzeby realnej refleksji. Nauka nie jest tu stara, choć wymaga szerokiej formy uaktualnienia i różnorodnych perspektyw, nowych modeli i bardziej szczególnych, a także ogólnych pytań i na dłużej wyznaczonych celów. Podstawowe problemy zyskują zasadnicze znaczenie w nauce ${ }^{33}$, co może po raz kolejny wobec przeszłości dobrze generować koncepcję powstająca w warunkach relatywnych. Wydawać się może, że żaden z dogmatów administracji i prawa administracyjnego nie jest ostatecznie zamknięty, często zaś dostateczną wskazówką mogłaby być złożona faktycznie myśl, że samo poznanie logiczno-językowe powinno uzasadniać badanie rozumiane empirycznie ${ }^{34}$.

prof. dr hab. Jan Boć

Uniwersytet Wroctawski

janboc@up.pl

Ernest Bojek

ern.bojek@gmail.com

THE SCIENCE OF LAW AND MODERN PUBLIC ADMINISTRATION

Sum mary

The aim of this research paper is deliberation on the essential problems of existence and functioning of public administration in modern times as well as on some issues of the science administration and administrative law. The description and argumentation cover a wide spectrum of issues relating to the review of contemporary areas of administrative activity as well as to

A. Wentkowska, Prawo Unii Europejskiej z uwzględnieniem Traktatu z Lizbony, C. H. Beck, Warszawa 2008, s. 4.; A. Wyrozumska, Jednostka w Unii Europejskiej, w: J. Barcz (red.), Prawo Unii Europejskiej. Zagadnienia systemowe, Wyd. Prawo i Praktyka Gospodarcza, Warszawa 2006, s. 405 i n.; K. Wójtowicz, Konstytucja RP z 1997 r. a członkostwo Polski w Unii Europejskiej, w: J. Barcz (red.), op. cit., s. 517 i n.

${ }_{32}$ Por. J. Rawls, Teoria sprawiedliwości, PWN, Warszawa 2009, s. 30.

${ }^{33}$ Zob. dzieło J. Zimmermanna, Aksjomaty prawa administracyjnego, Warszawa 2013, passim.

${ }^{34}$ Por. R. Carnap, Empiryzm. Semantyka. Ontologia, Warszawa 2005, s. 7 i n. W szczególnie przenikliwym kontekście zob. A. de Tocqueville, op. cit., s. 164 - wartość jego opinii wydaje się absolutnie uniwersalna: „Wszelka sztuka administracji jest na pewno wiedza, a wszelka wiedza, aby czynić postępy, musi łączyć w całość odkrycia kolejnych pokoleń”. 
the evolution of administrative structures and systems. A number of new terms, preliminarily developed, is therefore used. One of the features of contemporary legal and political processes is convergence of a global nature, which is a result of broadly understood globalisation, namely the internationalisation of all aspects of social life. Global convergence frequently leads to new standards, deregulation and new regulations. A particular research issue is supranational law, dynamically linked to public law and public administration.

The paper looks into the current condition of the science of law and calls for further cognitive studies. These include development of social doctrines and their personification in political and legal life, in particular. Here, the relationships between subjectivity and power are of significant importance. The processes of contemporary social life give rise to complex problems and administration must evolve together with society. It must be able to adapt to new circumstances and create foundations for innovative activities. Innovation and invention are the fundamental goal of administrative actions and functioning of administrative structures. They constitute the principal pillar of progress and development and belong to the most important legal issues of the contemporary world.

Centralisation continues to be essential as well. Administration faces an increasing range of tasks. The scale of needs multiplies, which then calls for new regulations and produces new legal issues. Regulation, interpretation of law, public interest, separation of powers, the rule of law, subjectivity and subjective rights are recurring issues and are comparatively manifested in many legal cultures, despite frequently varying phraseology and different levels of advancement in solving new legal problems. Solutions must be sought not only in doctrinal or system variables, but also in the specific variables relating to the organisation, control, supervision, or administrative police, and thus in these concepts and institutions that are fundamental for the science of administration and administrative law. 
Copyright of Journal of Law, Economics and Sociology is the property of Faculty of Law and Administration of Adam Mickiewicz University in Poznan and its content may not be copied or emailed to multiple sites or posted to a listserv without the copyright holder's express written permission. However, users may print, download, or email articles for individual use.

Właścicielem praw autorskich do „Ruchu Prawniczego, Ekonomicznego i Socjologicznego” jest Wydział Prawa i Administracji Uniwersytetu im. Adama Mickiewicza w Poznaniu. Zawartość czasopisma nie może być kopiowana, przesyłana do innych stron internetowych bądź zamieszczana na blogach bez pisemnej zgody wydawcy. Niemniej artykuły można drukować, kopiować lub przesyłać w formie elektronicznej na własny użytek. 